\title{
松代地震のメカニズム
}

\author{
気象庁地震課 市川 政 治 \\ (昭和 42 年 5 月 27 日受理)
}

\section{Statistical Study of the Focal Mechanism of Matsushiro Earthquake Swarm}

\author{
Masaji ICHIKAwA \\ Seismological Section, the Japan Meteorological Agency \\ (Received May 27, 1967)
}

Since August 1965, lots of earthquakes have been occurring at Matsushiro and its vicinity, northern part of central Honshu. In order to elucidate the cause of the peculiar phenomenon various kinds of observations and surveys have been done in the earthquake occurrence area.

On the basis of data obtained by the permanent seismological stations of the Japan Meteorological Agency and 5 temporary stations established in the area, the mechanism of earthquakes which occurred during the period from October 1965 to February 1967 was analysed.

The distribution of the initial motion of $P$ waves for the earthquakes is separated by two straight nodal lines, which are perpendicular to each other, and lie in the directions of $\mathrm{N} 35^{\circ} \sim 55^{\circ} \mathrm{W}$ and $\mathrm{N} 35^{\circ} \sim 55^{\circ} \mathrm{E}$. This suggests that the maximum pressure of stresses generating the earthquakes exists in the azimuth ranging from $\mathrm{N} 80^{\circ} \mathrm{W}$ to $\mathrm{N} 100^{\circ} \mathrm{W}$. The number of nodal plane solutions obtained is more than 300 .

Results of the statistical studies on the solutions and on the relationship between the focal mechanism and the geodetic surveys are summarized as follows:

1) The predominant directions of the pressures corresponding to the major earthquakes systematically changed by $10^{\circ}$ to $20^{\circ}$ on December 1965 and April 1966.

2) There exist systematic variations in the predominat directions of pressures in each earthquake occurrence area. This may be caused by the variation of local geology in the area.

3) The strike direction of $\mathrm{N} 55^{\circ} \mathrm{W}$ for one of the two nodal lines agrees well with the strike of fault produced by the earthquake swarm in the central part of the earthquake occurrence area.

4) The predominant pressure directions are in good harmony with the axes of contraction of horizontal strains computed on the basis of data obtained by the geodetic survey carried out during the period from November 1965 to August 1966 at the central part of the earthquake occurrence area.

\section{§1. まえがき}

1965 年 8 月以来, 長野県松代町周辺に群発している地震は約 1 年後の 1966 年 10 月に至りよ うやくその活動が衰え始めた。 しかし，この頃を境にして北は長野県山の内村，南は同坂井村 
に至る長円形の地域に地震が発生している.

このひえ発する地震を研究するため多数の機関により各種の観測・調査が行われている。こ こでは気象朾の常時地震観測網および松代町周辺に設置された臨時観測点で得た松代地震の $P$ 波初動に基づく地震のメカニズムの解析結果の統計，および起震歪力と測地学的現象との関連 性を述べる。

\section{§ 2. 資料および解析方法}

1965 年 8 月から 9 月末にかけて発生した地震のらち気象庁常時観測網の多数の観測点で $P$ 波初動の押し・引きが記録されたものはないので, メカニズムの解析は 1965 年 10 月以降のも のに限られる.

1965 年 8 月から翌年 9 月ころまでの地震活動域のほぼ中央に存在する皆神山が 10 万年ほど 前に噴出した溶岩円頂丘であることから，この地震群が地下岩しょうの活動に直接関係すると 考えるさきもあるが，ここでは，これらの地震が構造性のものであると仮定し，各地点で観測 された $P$ 波の押し・引きの分布からそのメカニズムを解析する.

今回の群発地震のらち, 資料の多数観測されたより大規模な地震の $P$ 波初動の押し・引き の分布は，日本付近に発生する大部分の極浅発地震のそれと同じように，互に直交する 2 直線 からなる典型的な象限型をしている。そこで，資料数が不充分で確かな節線が引けない場合 も，その $P$ 波初動の分布が互に直交する 2 節線で説明できるものと仮定して観測結果に矛盾 しない両極端の 2 組の節線を引き，その中間の位置を以ってこの地震の節線の走向とする． た，この中央值からのずれもあわせ測定し，解析結果の統計の際にその值を考慮する.

震央は原則として気象㕂の常時および臨時観測点の $P$ 扎よび $S$ 波の発震時から決定した ものを採用するが，震央が松代や長野など震央近傍の $P$ 波初動方向，押し・引きと矛盾する 場合は，その震央を計算された震央に対する標準誤差の程度に応じて移動することもある。

\section{§3. 解析結果}

1965 年 10 月から 1967 年 2 月までに松代町とその周辺地域に発生した地震のらち気象庁常 時観測網による資料を解析し, メカニズムの決定された地震の数は 87 に及ぶ. 上記のように ほとんどの地震の $P$ 波の押し・引き分布は遠方での不確実な資料を除き，互に直交する 2 本 の直線で四象限に区分されるので, 節線・起震歪力の主圧力・主張力は互にそれぞれ $45^{\circ}$ の角 度をなし, かつ, 主圧力・主張力の軸は地表に平行である. 参考をでに若干の地震の $P$ 波初 動分布を Fig. 1 に示す. 

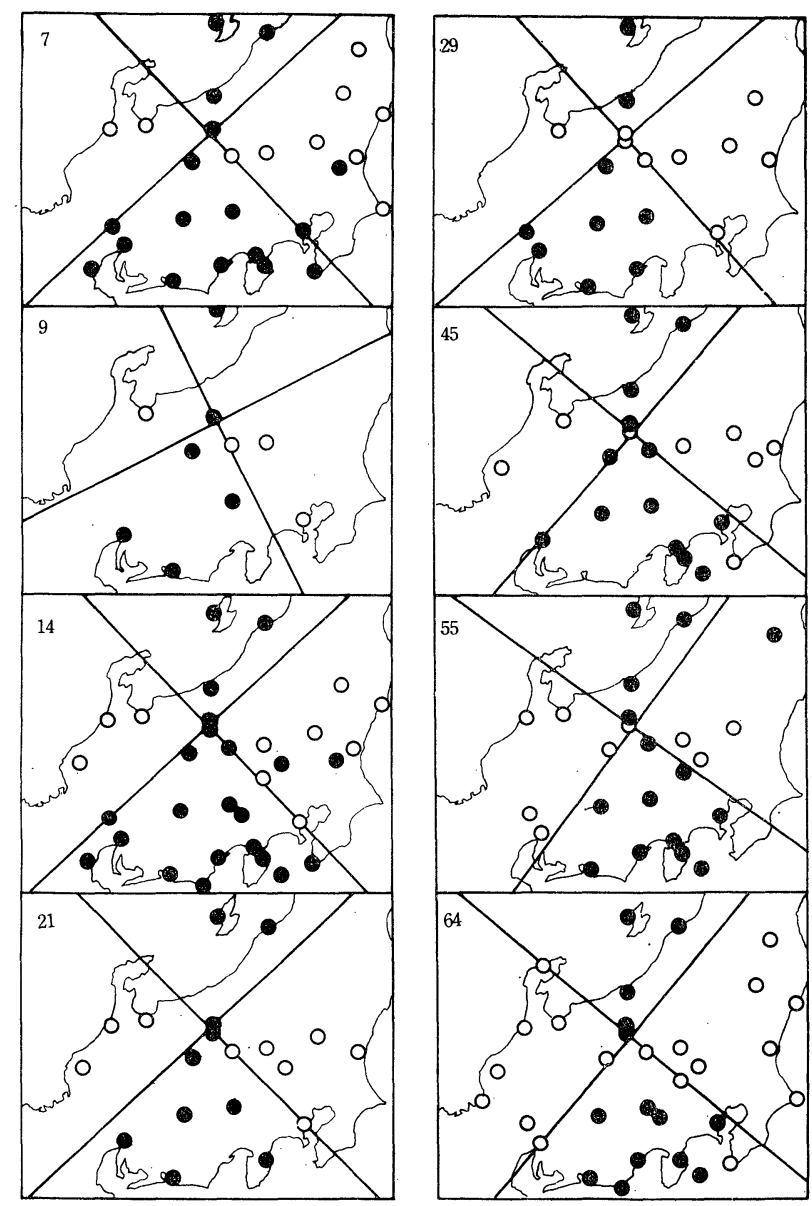

Fig. 1. Distribution of initial motion of $P$ waves for some earthquakes occurring in the vicinity of Matsushiro. - compression, $\bigcirc$ dilatation.

7: $02 \mathrm{~h} 57 \mathrm{~m}$, Nov. 23, $1965 \quad$ 29: 10h21m, Apr. 17, 1966

9: 0654 , Dec. 8, 1965 45: 0557 , May. 25, 1966

14: 2015 , Jan. 23, 1966 55: 0943 , June 12, 1966

21: 0525 , Apr. 1, 1966 64: 0348 , Aug. 3, 1966

1966 年 9 月以降は松代町周辺に設置された気象庁臨時観測点 (Fig. 6 参照) の資料から規 模 $2^{1} / 2 \sim 4$ の地震の震央が相当の正確さで決定され，同時に $P$ 波の押し・引きも観測されて いる.これらの資料によりメカニズムの解析された地震の数は 228 にぶ.

これらの地震のメカニズムの決定精度は解析に用いた資料数が少ないので, 常時観測網の観 測值に基づく結果にくらべて精度は落ちるものの，両観測網の資料から独立に求められた同じ 地震のメカニズムの解析結果は誤差の範团内で一致している。これらの解析結果は後日まとめ て発表する予定である。 


\section{$\S 4$. 主圧力方向の統計的研究}

一定の地域内に発生する小区域地震（最大有感距離が $100 \mathrm{~km}$ 以上 $200 \mathrm{~km}$ 未満の地震）以 上の階級の極浅発地震の主圧力は，少なくとも約半世紀に近い期間に得られた資料の統計によ ると，一般に時間の経過には無関係で，それぞれの地域固有の方向を持ち，かつこれらは地体 構造と関係しているようである（本多ら (1940)，(1952), 市川 (1965), (1966)).

1 年余に亘って発生し続けている松代周辺の地震のメカニズムがはたしてその活動の消長に 無関係に同じであるか，また，小地震のメカニズムもより大きな規模の地震と同じメカニズム で起っているのかなどを多数の解析結果に基づき調べる.

\section{1. 主圧力方向の時間的変動}

Fig. 1 からわかるように松代周辺に発生している地震のメカニズムは, 日本各地に発生す る極浅発地震と同じように，この地域固有のパターンを持ち主圧力は $\mathrm{N} 70^{\circ} \sim 110^{\circ} \mathrm{W}$ の範囲 内に存在する。この幅 $40^{\circ}$ のばらつきは単に偶然的なものか，あるいはまた地震活動の消長や 地震発生地域の構造に起因するものであろらか.

Fig. 2 に示した主圧力方向の時間的变化図かららかが学るように，この群発地震初期の 1965 年 11 月から 12 月上旬にかけて発生した地震の主圧力は東一西から時計回りの方向に多 少かたよっているが，同年 12 月中旬以降翌 3 年月頃までの地震の主圧力方向は上の期間のそ れにくらべて反時計回りの方向に回転している.

4 月になると主圧力の方向は更に同じ方向に回転し， 5 月以降の地震の 主圧力の方向は $\mathrm{N} 95^{\circ} \sim 110^{\circ} \mathrm{W}$ となっている。 このように松代周辺に発生したより規模の大きな地震の主圧 力方向は時間の経過にともない，系統的な変化をしているらしいことがわかる.

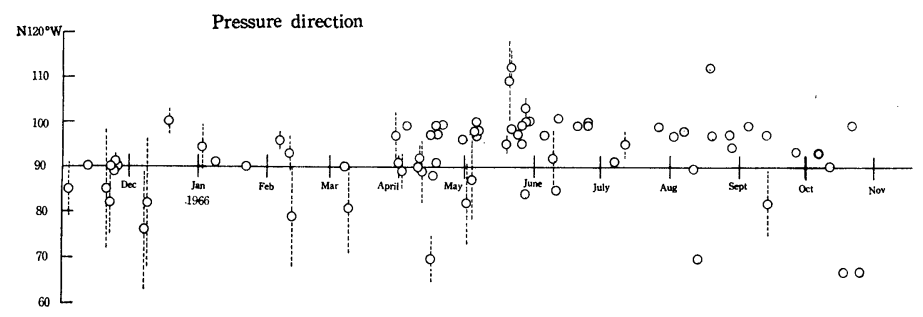

Fig. 2. Pressure direction vs time.

Fig. 2 の主圧力方向の状態を考慮して，1965 年 11 月 12 月上旬， 12 月中旬 1966 年 3 月 上旬， 3 月下旬 4 月中旬， 4 月中旬 6 月下旬， 7 月上旬 $~ 8$ 月下旬，拈よび 9 月上旬 10 月の各期間内に発生した地震のメカニズム解析結果をそれぞれ一群とし，一元配置法にもとづ き, 各群間の主圧力の平均方向の差異存在の有無を調べたところ, 各期間に発生した地震の主 
圧力の平均方向が同じであると言う仮定は $1 \%$ の危険率で棄却され，主圧力の卓越方向が時間 的にある変化をしていることが明らかとなった。

上の結果はメカニズムの解析できた規模の大きな地震についての統計結果であるから，これ がメカニズムの決まらなかった小地震にもみられるかどうか調べる必要がある.

1965 年 10 月〜1966 年 12 月までの期間を上の統計検定の際に採用した時間区分を基礎にし て 12 期間に分け，それぞれの期間内に発生した地震のうち，少なくとも震央付近の 5 観測点 で $P$ 波の押し・引きが観測された地震を用い，各観測点で観測された $P$ 波の押し・引きの 回数とその比を求めた。 このようにして求めた各点の押し・引きの回数とその比の分布図を Fig. 3 に示す.
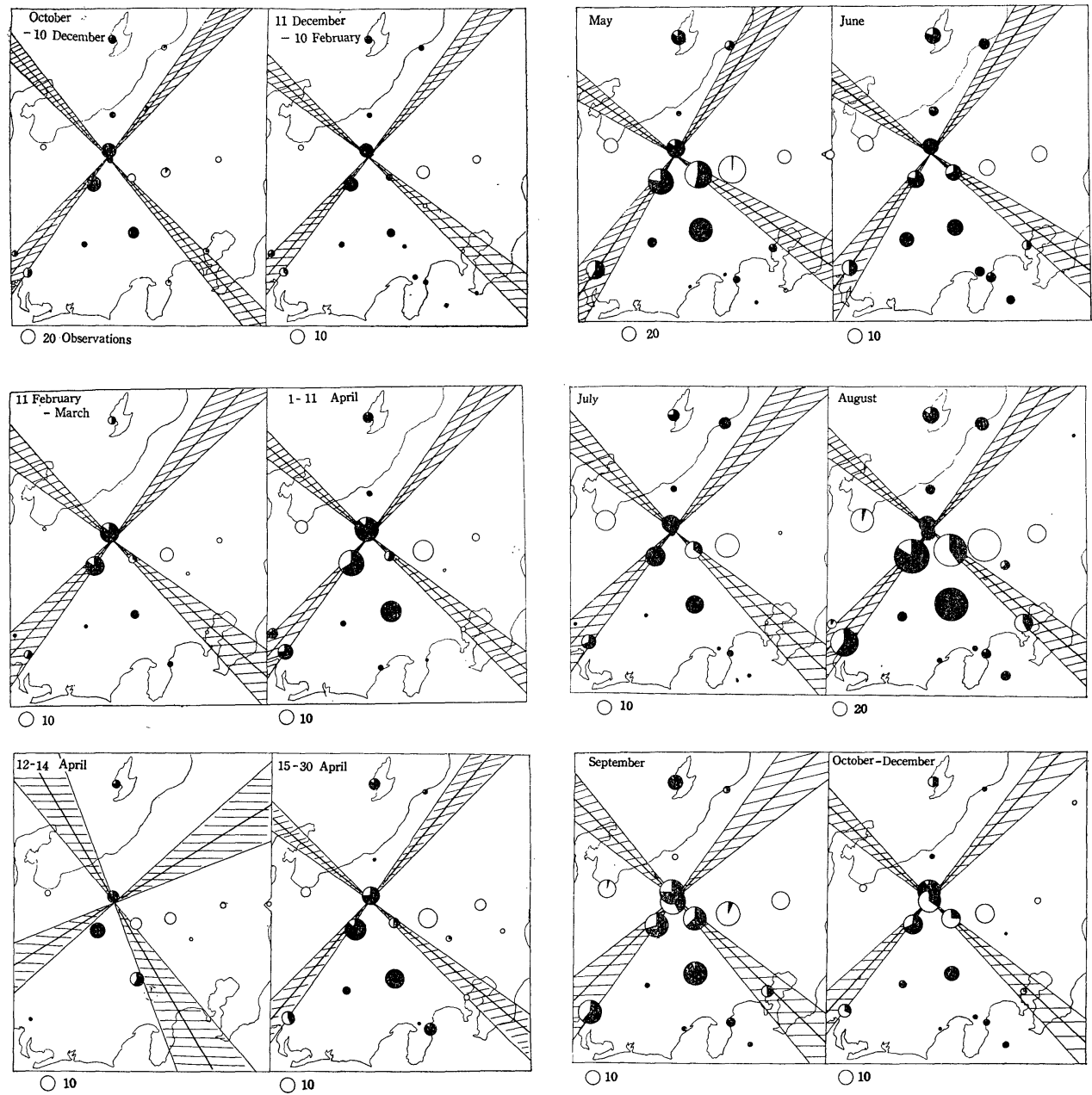

Fig. 3. Distribution of the ratio of compression (black portion) and dilatation (white portion) of $P$ waves for earthquakes in various periods at each station. 
各図のうち, 節線付近の観測点の長野・松代・松本・軽井沢・名古屋等に特に注目して地震 のメカニズムの時間的変動を調ベる.

1965 年 10 月から 12 月上旬にかけて発生した地震のらち, 上の条件に属する地震に対する 松代・長野・松本の $P$ 波初動はすべて押しであるのに対し, 12 月上旬から翌年 2 月上旬に掠 ける軽井沢の初動はすべては引き波である. 軽井沢の $P$ 波初動の状態のこの恋化は, 第 2 期 に打ける地震の主圧力方向あるいは節線の走向が反時計回りの方向に多少回転したことを示唆 する.

1966 年 2 月以降になるとそれまで押し 波しか観測されなかった松本に引き波で始する地震 が観測され出し，それ以前に比して更に反時計回りの方向に回転した主圧力を持つ地震が多く 発生し出していることがわかる.

同じ状態は 1966 年 12 月ころまで続いているが，ただ 1966 年 4 月 12 日から 14 日にかけて 発生した地震のうちに, 甲府に引き波を与えるようなメカニズムを持つ地震が発生している. 軽井沢の初動はすべて引き波，松本のそれはこれに反してすべて押し波であることなどを考兄 ると，この期間には東一西方向から時計回りに $30^{\circ} く ら い$ 回転した主圧力方向を持った地震が 発生していると言える.

小地震を含めたこの統計的調査結果は, メカニズムの解析された地震の主圧力の卓越方向の 時間的変動, すなわち, 本群発地震の初期に和ける主圧力の卓越方向と中期以降のそ机との間

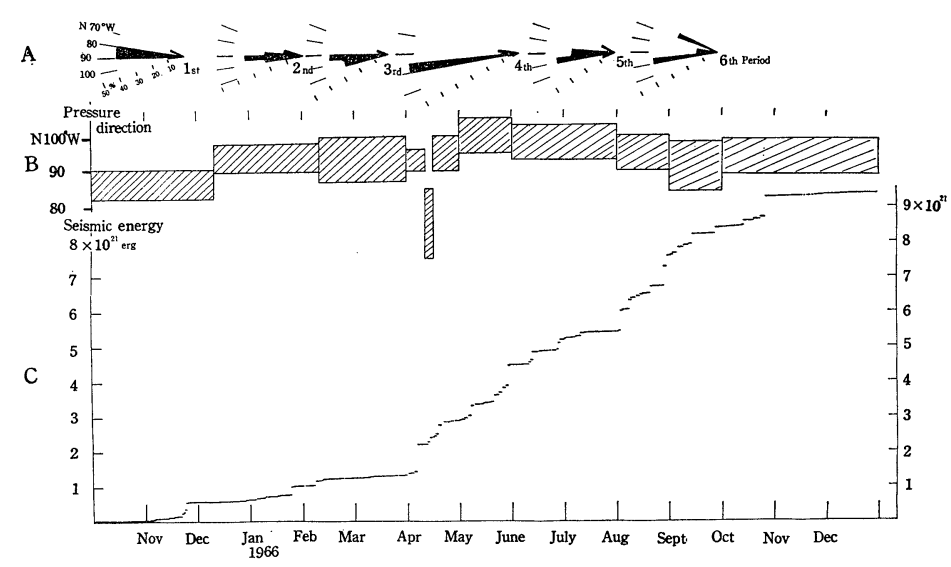

Fig. 4. Percentage of pressure directions for major earthquakes occurring in various periods (A), upper and lower limits of pressure directions inferred from the superposed distribution of initial motion of $P$ waves for earthquakes including smaller ones (B), and the cumulative seismic energy released by earthquakes whose epicenters were determined by JMA (C). 
には $20^{\circ} \sim 30^{\circ}$ の系統的な変化があるといらことと矛盾しない．また，この調査によると地震 のメカニズムの変動はより複雑で，2３日から 1 2 カ月の時間単位で系統的な変化をしてい るようにみえる。

Fig. 4 飞各期間に拈ける主圧力方向のひえ度分布，重畳初動分布図から推定した主圧力の 卓越方向, および気象庁決定の地震の規模から算出した 1965 年 11 月～1966 年 12 月までに松 代町とその周辺で放出された地震のエネルギーの積算図を示寸。これらの図から地震活動の活 発化した 1966 年 4 月〜 6 月の地震発生のメカニズムは心持ち，その前後のそれと異なること がうかがえる。

\section{2. 主圧力方向と地震の規模}

ある限られた地域に発生する地震の主圧力方向は，地震の規模が小さくなるに従ってその分 布の規則性が乱れてくると言われているのでこの点を調べてみる.

前記のように松代の地震の主圧力の卓越方向 は時間の経過に伴い $20^{\circ} \sim 30^{\circ}$ の系統的变化を しているらしいので，Fig. 5 の主圧力方向一 地震の規模の関係図はこの点を考慮して作られ ている.

この図から 1965 年 11 月 1966 年 3 月まで と, 1966 年 7 月以降の地震の主圧力方向の散ら ばりは，地震の規模が小さくなるに従って確か にその幅が大きくなる：全資料を通してみると き $\mathrm{N} 100^{\circ} \mathrm{W}$ より大きな主圧力方向を持つ地 震は 3 例に過ぎないことは面白い.

この $\mathrm{N} 100^{\circ} \mathrm{W}$ といら主圧力方向に対応す る一節線の走向 $\mathrm{N} 55^{\circ} \mathrm{W}$ は, 松代地震に伴っ て発生したと思われる断層の走向と同じである が， $\mathrm{N} 100^{\circ} \mathrm{W}$ より反時計回りの方向に回転し た主圧力方向を 持つ地震が少ないと言うこと

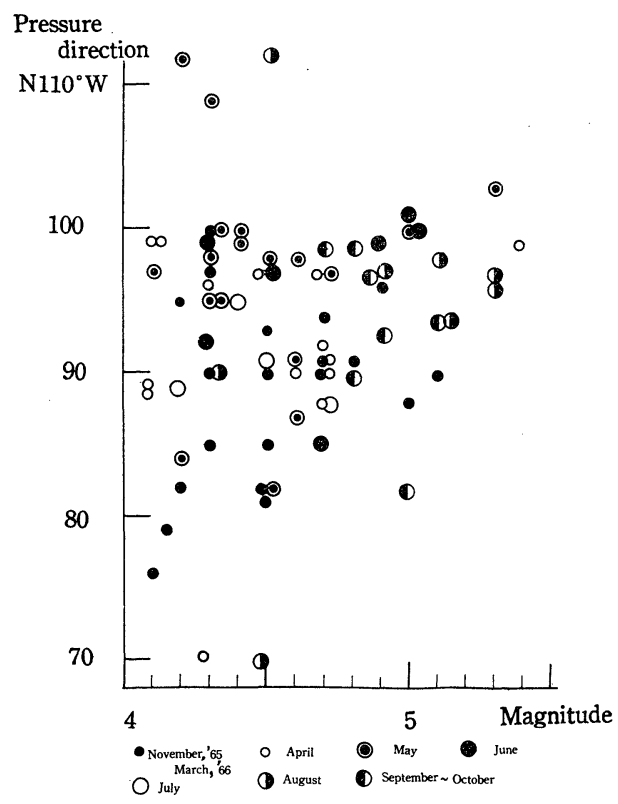

Fig. 5. Relation between earthquake magnitudes and pressure directions in various periods.

は，上記の地震断層の発生と関係があるのかも知れない。

\section{3. 小規模地震の主圧力方向の地域性}

臨時観測点での観測資料にもとづく震央決定の正確さは $1 \sim 2 \mathrm{~km}$ であり，また，この小 規模地震のメカニズムは地震発生域が拡大した 1966 年 9 月以降のものであるから地震のメカ 


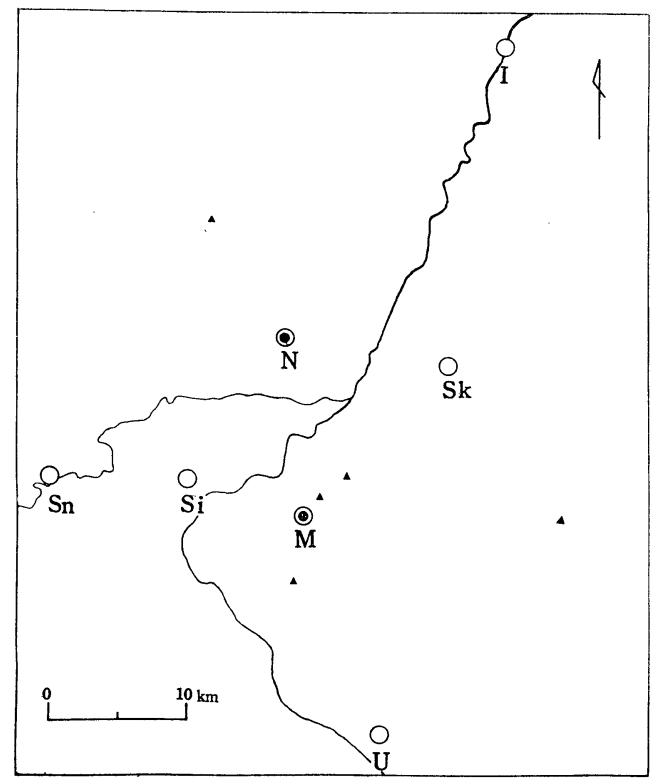

Fig. 6. Distribution of JMA permanent and temporary stations in the vicinity of Matsushiro

N: Nagano District Meteorological Observatory

M: Matsushiro Seismological Observatory

$\mathrm{U}$ : Ueda temporary station

I: Iiyama temporary station

Sk: Suzaka temporary station

Sn: Shinmachi temporary station

$\mathrm{Si}$ : Shinonoi temporary station (Nov. 1966 to Dec. 1966)

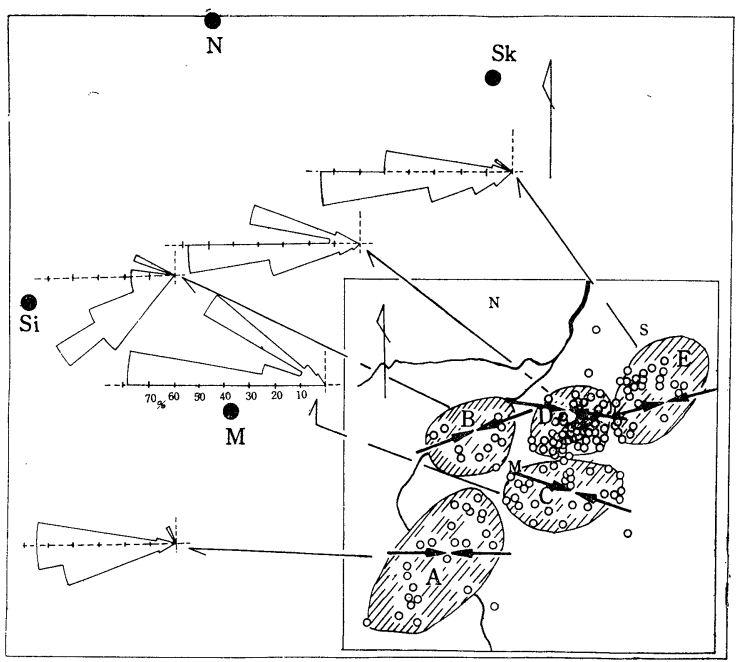

Fig. 7. Distributions of locations of earthquakes whose mechanism was determined, percentage of pressure directions, and mean pressure direction in each area. 
ニズムの地域性を調ベるには都合がよい.

地震発生域を震央の分布密度や個々の地震の主圧力方向の分布の傾向を考慮して Fig. 7 に 示した 5 区域に分け，一元配置法で各地域の地震の主圧力卓越方向のあいだの系統的差異の有 無を検定した。 その結果によると各地域間の主圧力の平均方向のあいだに差がないと言ら仮定 は $5 \%$ の危険率をもって棄却される.

各地震の主圧力方向は同じ正確さで決められていないので, 主圧力方向の可変範囲に応じ, 下のような荷重を乗じて平均方向を求めた.

\begin{tabular}{|c|c|c|c|c|c|c|}
\hline 可変変 & $0^{\circ} \sim 5^{\circ}$ & $0^{\circ} \sim 10^{\circ}$ & $11^{\circ} \sim 15^{\circ}$ & $16^{\circ} \sim 20^{\circ}$ & $21^{\circ} \sim 25^{\circ}$ & \\
\hline . & 1.0 & 0.25 & 0.1 & 0.06 & 0.04 & 0.0 \\
\hline
\end{tabular}

Fig. 7 には主圧力の平均方向の計算に用いた地震の震央, 各地域の主圧力方向のひん度分 布㘧よび主圧力の平均方向 $\left(\mathrm{A}: \mathrm{N} 90^{\circ} \pm 3.2^{\circ} \mathrm{W}, \mathrm{B}: \mathrm{N} 111^{\circ} \pm 5.5^{\circ} \mathrm{W}, \mathrm{C}: \mathrm{N} 79^{\circ} \pm 1.5^{\circ} \mathrm{W}, \mathrm{D}\right.$ : $\left.\mathrm{N} 82^{\circ} \pm 1.5^{\circ} \mathrm{W}, \mathrm{E}: \mathrm{N} 105^{\circ} \pm 2.5^{\circ} \mathrm{W}\right)$, 女示す.

この図から C および $\mathrm{D}$ 地区の主圧力の卓越方向は他の地区のそれに比して $10^{\circ} \sim 20^{\circ}$ ほ ど反時計回りの方向にずれていることがわかる。この C・D 地区は松代地震観測所の南の地域 から若穂町にかけての地域に当り, 群発地震発生当初から 1966 年 9 月ころまでの地震活動域 に相当する.さらに，この卓越方向は Fig. 5 の結果と矛盾しない.

\section{§5. 地震のメカニズムと地震に伴う地形変動}

極浅発地震の起震歪力の主圧力方向と土地の雪の状態が中部日本以西の各地でよく調和し ていることが笠原ら（1964）により見出され，市川（1965）により確認されている.

今回の群発地震に当り笠原ら（1966）はデオディメータにより松代周辺の土地の歪を測定し ているが，その結果によると少なくとも 1966 年 9 月ころまでの当該地区の土地は, 時間の経 過に伴い多少の変化はみられるが，東一西方向に縮み，南一北方向に伸びている．この現象は 起震歪力から推定される状態とよく一致する.

地震活動の最盛期にあたる 1966 年 8 月ころに皆神山近辺の地域に 発生したがえ行状の地割 れ群や，三角測量の解析結果などからこの地区に $\mathrm{N} 55^{\circ} \mathrm{W}$ に走る水平断層の発生が推定され ている.この断層の走向は 1966 年 4 月以降に拈いて当該地区に発生したより大規模な地震の $P$ 波の一節線の走向とほぼ一致する。ただ，1966 年 9 月以降は地震が上記断層の走向と直角 の細長い地域に発生している事実は注目に值する.

一方, 1966 年 8 月ころ皆神山周辺で土地が異常に隆起しているが，この隆起量は水平断層発 生と関係づけるにはその值が大きすぎるようである. 


\section{$\S$ 6. 中部日本における過去の地震のメカニズム}

松代地区を含む中部日本に発生した極浅発地震の起震歪力の状態や松代周辺地区に発生した 地震の $P$ 波初動分布を 1926 年から今回の群発地震直前までの資料にもとづき調査する.

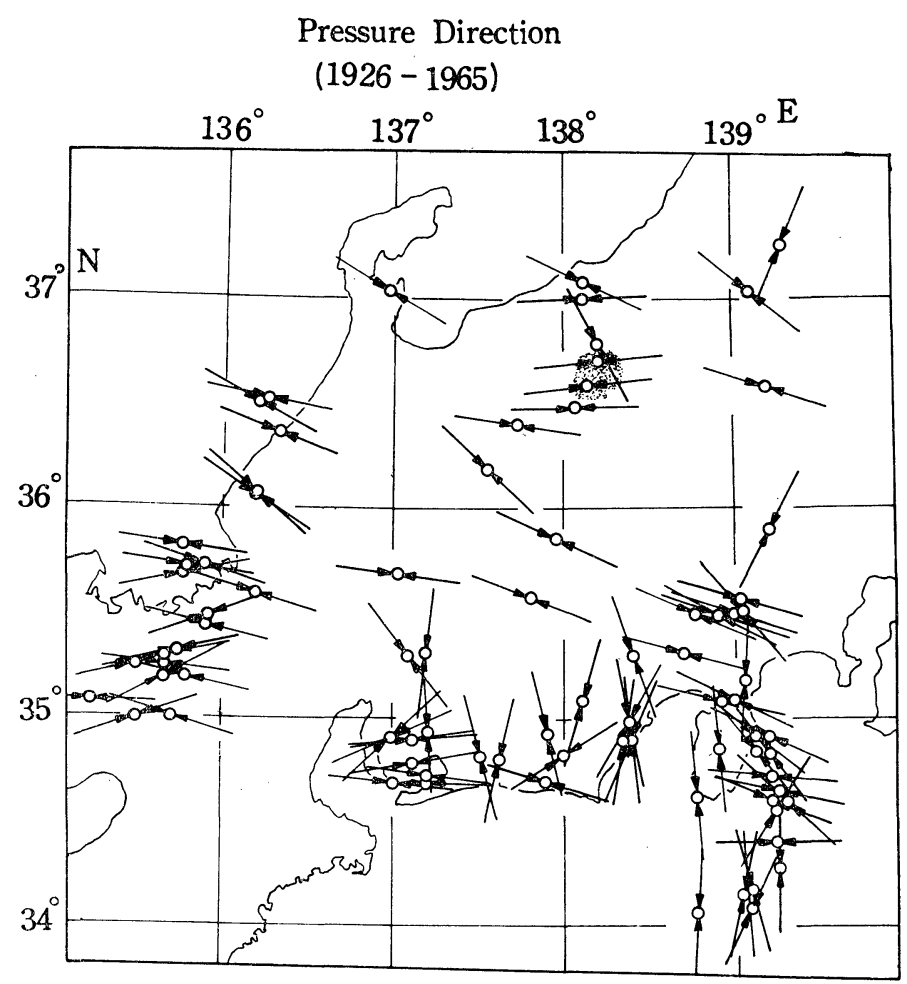

Fig. 8. Pressure directions of earthquakes occurring in central part of Japan $(1926 \sim 1965)$.

Fig. 8 は 1926 年から 1965 年までに中部日本に発生した極浅発地震の主圧力方向の分布 図であり，Fig. 9 は過去に松代周辺に発生した地震の初動分布図である.Fig. 8 中の翏 の 部分が今回の群発地震発生域に当るが，この地域の北のはずれに発生した 1943 年 10 月 13 日 の野尻湖付近の地震や，メカニズムが解析できなかった 1941 年 3 月 7 日の地震を除けば, こ の地域の地震は今回の地震のメカニズムとほとえどそのメカニズムが同じであることがわか る.

今回の群発地震発生域から少しはずれた長野県山の内村に 1966 年 11 月に発生した一群の 地震や同年 12 月に新潟・長野県境近くの飯山に発生した地震のメカニズムは, 1943 年の野尻 湖の地震と同様にそのメカニズムは松代地震のものと多少異なる。この地域差は执そらく地殼 

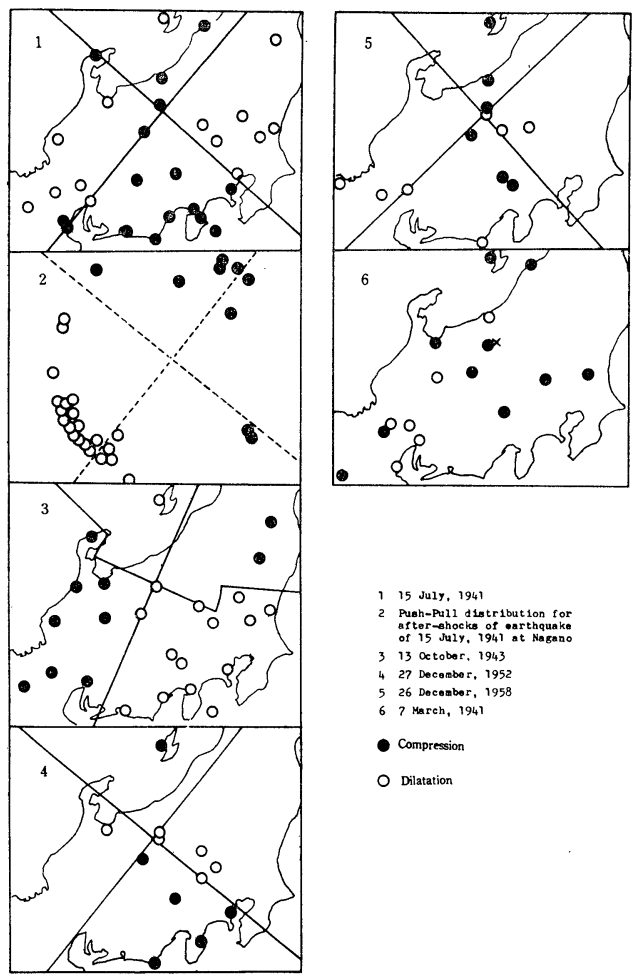

15 Ju1y, 1941

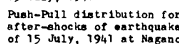

13 cetobor, 1943

427 Decomber, 1952

526 Decomber, 1958

Compression

O Dilatation

Fig. 9. Distribution of initial motion of $P$ waves for earthquakes occurring in the vicinity of Matsushiro in the past (1926 1958).

上層の地質構造の差異によるものだろうと思われる.

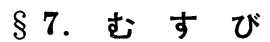

松代付近に発生した多数の地震の $P$ 波の押し・引きの分布から推定した地震のメカニズム は，測地学的現象とよい調和を示している．また，今回の地震のメカニズムは過去にこの付近 に起った地震のメカニズムとも非常によく一致している.

各地震のメカニズム同志も非常によく似ているが，これを統計的に調べてみると，時間・空 間・地震の大いさに関係した系統的な変化やかたよりが存在することがわかった。

この時間・空間的な系統的差異は各時点に括ける地震活動の中心地の地殼上層の地質構造に 多かれ少なかれ関係するのではないかと思われる。 


\section{文献}

本多弘吉・正務 章, 1940, 本邦付近の地殼内部に㧍ける起震丕力について, 験震時報 11, 183 219. Honda, H. and A. Masatsuka, 1952. On the Mechanism of Earthquakes and the Stresses Producing Them in Japan and its Vicinity. Sci. Rep. Tohoku Univ., 5, Geophys. 4, 42 $\sim 60$.

Ichikawa, M., 1965, Mechanism of Earthquakes Occurring in Central and Southwestern Japan, and Some Related Problems. Pap. Met. Geophys,. 16, 104 156.

市川政治, 1966, 日本付近の地震のメカニズムに関する統計的研究と二, 三の問題. 研究時報 18, 83 $\sim 154$.

Kasahara, K. and A. Sugimura, 1964, Horizontal Secular Deformation of Land Deduced from Retriangulation Data, Land Deformation in Central Japan. Bull. Earthq. Res. Inst., 42. $479 \sim 490$.

Kasahara, K. and A. Okada, 1966, Electro-Optical Measurement of Horizontal Strains Accumulating in the Swarm Earthquake Area (1). Bull. Earthq. Res. Inst. 44, 335 350. 